\title{
Gender, Identity and Multiculturalism in the Context of the European Union
}

ESSAY

Rosi Braidotti var en af hovedtalerne pai 3rd European Feminist Research Conference, Portugal 1997. Rosi Braidotti fremstair som tilhanger og arbejder selv indenfor $E U$ regi (ATHENA og SOCRATES programmer). Hendes essay diskuterer konstruktioner af nye europaiske identiteter $i$ de nuvarende magtdiskurser indenfor EU. For Braidotti er $E U$ et projekt, boor den reaktionare, europaiske nationalisme kan boldes $i$ ave, men bun ser ogsai faren $i$ EU for cementeringen af et Fort Europa, som kan bave katastrofale folger for de som lukkes saivel ude som inde. Bradotti efterlyser en kritisk intellektuel debat.

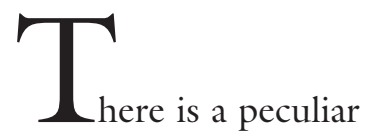
construction of identities going on. In NATO it is happening in Central Europe, where ever one is talking about safety, talking about security. And then the European Union is coming in, with all its frills: Culture, and popular education. If you're looking just at history - not so much in terms of straight power relations - looking at divisions of labor and also gender relations, then NATO can either harden those business and the European Community can remain at the frills.

There are peculiar things going on, decisions are being made, we women citizens, or residents of this part of the world, have very little to do with. What I am offering here is an idea of European identity as a contestant identity.

The European Community is not a very unified block. It is a contestant, open and very volatile area, in which enormous parts are being laid out. 
The disfunction of NATO, which prepares for the militarization of the new Europe, is crucial especially for Eastern Europe. As women living in this area, (even though we have not solved the problems of citizenship at a national level, a question we have never solved historically), we are projected forward into larger, more complicated issues of citizenship at supernational level, at trans-national level, and we are very rapidly losing ground, in terms of making an impact. I see the theme of the conference as great variables, in terms of the inscribing the possible forms of action, agency and resistance of women, as citizens of a contestant space, a space where power relations are at work constantly.

The question of contestant identity have received much interest, since structuralism and beyond. Since Marxism and social sciences and beyond, there has been a lot of really important work being done on not taking identity as a given, either biological or historical essentialistic sense. It is never just given, it is never written in your genes, it is never written in your history either. I have to mention the work Foucault has done on this, to mention one: You can not distinguish identity, from which the way it is embedded in a set of social discursive relations of power. So in a sense, identity says it all, and says nothing. It is embedded and embodied in a web of power relations, of discursive relations, of dicursive practices, that makes it an absolute explosive, and at the same time, a very slippery thing. It is not one thing, it is a set of relations. The same way gender is not one thing, it is a set of relations. It is a bundle of variables, that connect the two, a whole web of social discursive practices. It is about class, it is about the colour of the skin, it is about religion, it is about age, it is about a number of those things that flood you into a network of empowerment of entitlement, so again it says everything and it says nothing. Identity is only the way in which we name a set of discursive social surrounding relati- ons. Gender theory has shown how identity functions as a conveyer belt, that carries you into certain types of constraints. Gender is a set of relations; that alone would put women's studies and research theory at the foreground of contemporary projection of identity. And I would ask, that when we talk about European identity, we approach it in this manner. It is always this condition as a set of variables. This particular complicated global empowerment and how we define global economy, is again under these contestant notions. For the sake of the argument, of the development of the paper, I propose a working definition of the historical moment, of the global economy, in terms of a persistent paradox: The pairs of simultaneously opposed events: Globalization and capitalization. Everybody reads this in newspapers, everybody watches TV, that there are enormous internal differentiations: The European Union is falling apart.

This is one of the many possible definitions, but the question of identity, cannot be resolved in the classical early twentieth century term: What is identity, what is gender identity, what is national identity, what is ethnic identity? It is not a 'what-question', it is a genealogical and critical question. How is identity constructed? By whom and under which conditions and who profits from it. It is a 'how-and-where' question, not a 'what-question'. As Stuart Hall puts it: This issue of identity is about entitlement and access. It is about agency and the question is not, who is a European citizen, but who is allowed to call oneself a European citizen. It is about access and participation, rather than questions of origins or so. Struggles go on to argue inconsequently, and postmodern racism has taken a very different form, not only essentialists definitions of points of origin, but the tight control of points of access and points of entry and access to participation. Consequently racism changes shape in such conflicts. What is the interesting, rather progressive potential of this European project at a time 
where identity is defined, is what I would like to emphasize, what I see as a potential positive reframing of the European part, of European citizenship at this particular point in history. Now in social sciences of the post kind - you can be post-structuralist, you can be post-modern, you can be postcolonial, you can be post-feminist, you can be all kinds of post - but one thing they share, is a discourse about the crisis of $\mathrm{Eu}^{-}$ ropean identity. It means different things to different disciplines, it comes in from different angles, but there is a kind of coalition around a discourse on the crisis of Europe. You will find this in a lot of social sciences. You will find it in much reactionary literature, that is traditionalists, which is always concerned about the decline of Europe. What I would like to propose, is that we take perversely, maybe, the discourse about the crisis of Europe; the decline of Europe as hegemonic, as we take that as the dominant discourse about Europe today, perpetuated itself through a discourse, on the crisis on so-called European values. And ask, what exactly do you mean, when you talk about European values? There is always some crisis of European values going on somewhere, to discuss or to have conferences about, so let us take a discourse about a crisis of Europe, as a dominant discourse, as a hegemonic discourse, perversely, because it is a discourse about weaknesses, about losing power. How about a discourse about Europe losing power, as the dominant power-discourse today? For instance, the coalition between post-colonial discourses, and the discourse about the post-structuralist deconstruction of identity, come together in a much stronger, slightly asymmetrical and perverse manner. We must not confuse the post of post-coloniality, with the post of post-modernism, but must respect the specific historical locations of each. The parallel of the three post-colonialism, postmodernity and post-structuralism, is at least sufficient condition for a dialogue between the two of them, to get started, of the loss of power of hegemonic Europe. The copy of something called the post-colonial condition, where new strong subjectivities are emerging, once used to be the periphery of the empire. As Gayatri Spivak has put it, very beautifully: "The theories of the decline of Europe are happening within the first world. The manifestation of the decline of Europe is happening in the coming of the global economy - that is happening in the fastest growing economies in the world, and it being outside of Europe". There is again a peculiar simultany of opposite effects. Now, the dialogue between the postcolonial position and post-industrial position, which inscribes issues of etnicity and race, at the heart of the debate, not the periphery, but at the heart of the debate about European identity. It is precisely about issues in terms of periphery and center. The significant thing, Spivak, Paul Gilroy and many others have talked about in terms of the politics of this post-condition, as one of the differences that shall emerge, not between cultures, but within the same culture. It is not the difference between center and periphery, but within. One of the central paradoxes of this is dialogue you can call post-modernity or post-industrialism, is the shifting ground in which periphery and center are pinched against each other, in such a complex manner, as to defy dualistic oppositions. It is no longer as simple as 'us and them', it doesn't work in the age of global economy, where the fastest growing economies are outside of the First World. So we need to complex the way in which we are looking at the blocks. The dualistic oppositions no longer do justice to the perversity, the schizophrenia of our times. We need to look at differences. It is in this context I wish to stress, what I see as positive and illuminating about the European Union, of European citizenship. And here you can shoot me down, because it is a bit utopian, but I want to stress the extent, to which the notion, to which the European citizenship is an attempt, to give a positive 
answer, to the issue of identity, at a time in history, that is defined as an alarming globalization and fragmentation, the simultany of opposite effects.

The first thing I want to recall, in terms of the positive progressive potential of Europe, is a point of history, is that Europeans never wanted it. We forget this, because the discourse of the European Union is today, in the newspapers the discourse of power. The European Union, was something that was imposed upon us, after the Second War World. It was imposed, on the ruins on fascist, holocaust ridden Europe, it was the American and Allied forces who had had enough of Europeans fighting each other to death. We had fought two European civil wars, that went by the name of world wars of the crucible empire and colonial power, and the second time it was almost fatal. The USA said 'okay, never again'. We do forget that the origin of the common European space, is the question of European fascism and the role it played in the Second World War. I had the great privilege of talking to Albert Hirschmann, who was on the staff of the US government, when they rebuilt Europe, and this is the 50th anniversary of the Marshall plan this year. We may remember this historically; they had to fight an uphill battle to get De Gaulle, Adenauer, or whoever was around, to get them to accept what is the most difficult thing for any European to accept: The decline of national power. This is what the European Union stands for: The decline of nationalism and national power, and the surrendering of national power to a socalled centralized bureaucracy. Now we get into the parallel of discourse of euroscepticism, but let me assume a positive argument on this. We didn't want it, nobody in Europe wanted it, because we are deeply rooted nationalists, so it is absolutely crucial to see how European Union citizenship needs historically, to be pinched against, what it is supposed to be an alternative, to which is good old fashioned European nati- onalism. If you do not believe me, look at what is happening in European elections. Look at where the opposition to the European Union is coming from. In most $\mathrm{CO}^{-}$ untries in the Union, it is coming from the nationalistic right and it is coming from the nostalgic extreme left, who believes all power is evil, and should be destroyed in any case. That is going on under our very noses and shouldn't it alert us and if not convince us, that the germ or the virus of European nationalism has simply shifted from the national level, to the regional. It has gone down one floor, but it is as pretentious? as ever. It has been said, the great contestant of political identities today, is a common European Union citizenship. Let us look at the politics involved in this, and let us look at the European Union, as a possible alternative to this nationalistic thing. Of course I can see the immediate objections, what the immediate problems of this is, and the immediate problems of this is the possibility of recreating a supercentralized mega-state, - fortress-Europe in the form of a super national state. That is the obvious danger and the danger to which anti-racist feminists has alerted us saying: Be very careful. This transition of power to a super national state, without the risk of going from eurocentrism in the classical modernist mode, to europe-ism, that is to say a 'hurrah, hurrah' for a European fortress, that would be as disastrous for those that it locks out, as well as for those it locks in. The danger is there. But bear with me on the sunny side for a little bit longer. I do not believe, and I repeat, as I stated earlier, this battle is still going. I don't think it has been decided; it is a contestant space. It is an open political struggle, in which I believe feminist should play a much bigger role. It is not over yet; we can still do something about it. We can do something about it. But the absence of input by progressive critical intellectuals into this debate in Europe, worries me. That is why I wish that you bear with me on the optimi- 


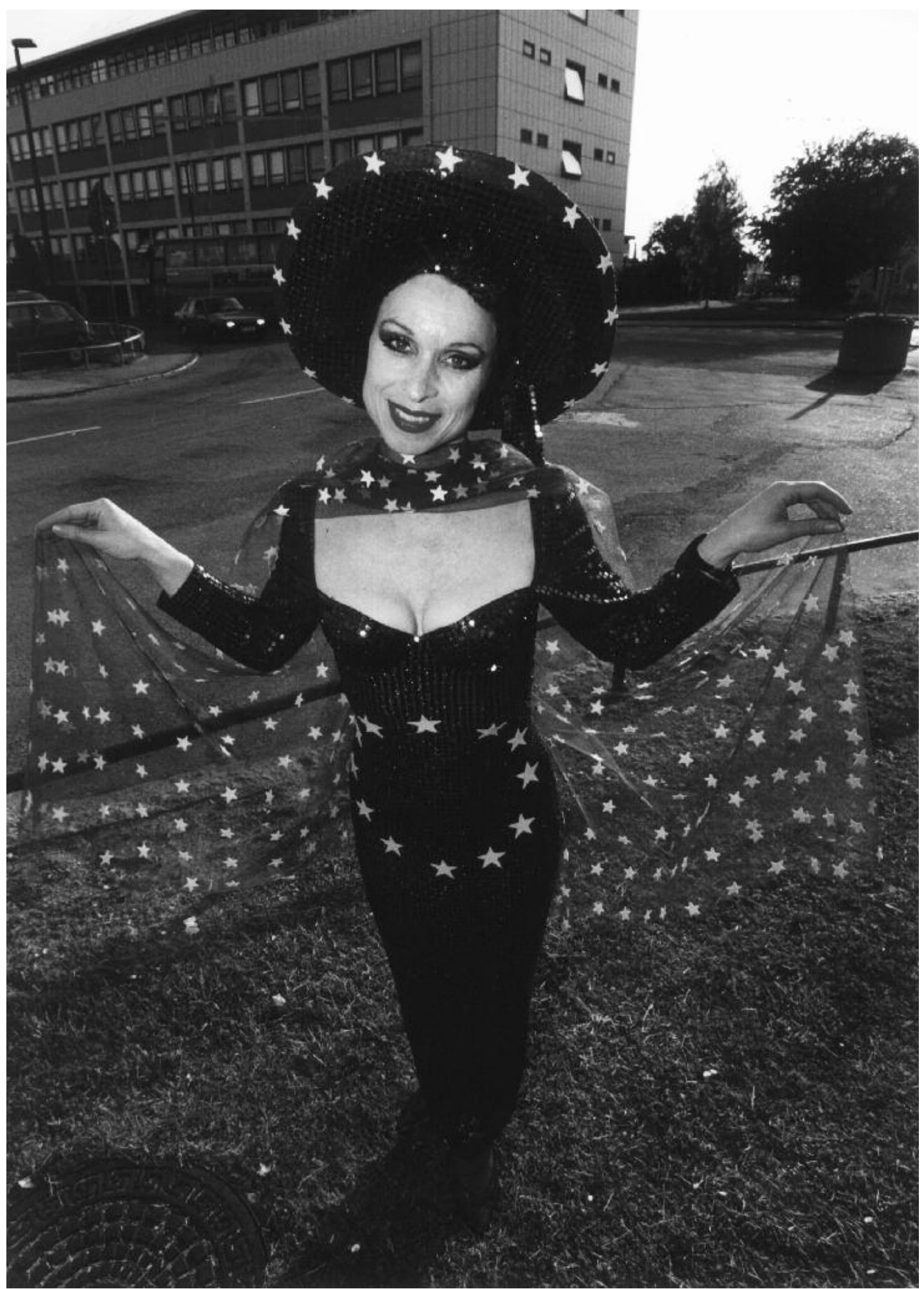


stic side. You have this historical legacy, that European Union being the alternative to classical nationalism, not that it works, because it has simply shifted nationalism to the regional level. But still, those structures are there. Now, why the classical definition of classical European identity is hegemonic, is the obsession with the idea of Europe as the center. If you read the definition of Europe the European Union has given: "What is Europe?" Europe is the land of the Rights of Man. Is the place of the separation of the church from State. The ideals of the French Revolution is the definition you will find in the document of the European Union, which is looking at the sunny side of the story. I would be much more critical of that version, because I am a lot more clearheaded about the history of Europe. One of the things that defines the European hegemony, is the ability to act as the center, which we call the universalistic pretension. Passing yourself off as the center and confining the rest of the world as one great big periphery. We did it with metaphysical philosophy, we did it with empires, we are doing it with technology; we are good at that. We are the West, we're the best. Feminists have criticized this centrism, this ability to actually constitute yourself, as some sort of center, in terms of metaphysical cannibalism. Metaphysical cannibalism means the systematical and highly throw out consumption of 'others'. One of the ways, to define Europe, is the consumption of female bodies. I would say Europe has been consuming all sorts of bodies, since the high days of modernism. And one definition of modernism is both the construction and consumption of figures of 'otherness', which can be as exactly metaphysically consumed. The classical 'others' of modernism are certainly women, but also the ethnic 'other', and the natural 'other' whether it is the environment, animals or children, these were disposable bodies. This can be one definition of Europe, you can say other cultures have done it too, Japan is not much better. I am very much prepared to accept that, but I do see this characteristic very clear, this passing off as the center and not just as some innocent type of megaglomania, it is a very deliberate political economy of construction of consumption of 'others'. Now in the global economy, Europe is off-center. It is the decentering of Europe that marks the global economy. The fastest growing economies are not here. We're going down folks, we are also getting old. We are not the center. We are one great big periphery. The decline of the nation state is a set of complete economical and political organizations. The coming of the electronic frontier and the information highways, accelerated the process of dematerialization of the nation state. Very soon the nation state will be in museums of folklore, as the language and culture of certain nations. That is all there will be. National values will decide something else. This situation has created a wave of resistance and nostalgia about the population. I am not giving any of this as being very simple solution. They are very contestant. Nonetheless it is a fact. It is a fact that the definition of the global economy is the decentering of Europe. Europe has to rethink itself as a periphery. Now that's a hell of a crisis, for a place that has perfected the art, of passing itself off as the center. If you look at social science, political science, research at the moment, people are doing acrobatics to come to terms to try to avoid the harsh reality: Folks, we are the periphery. Nostalgia and resistance to this, are features of our time. Now in a conference like this, in a context where the politics and economics are organized in this way, and NATO is doing what we cannot do, and that it is military control over our borders. And it is in this context, that the European Union for the first time in 50 years puts on the agenda cultural identity. If you look at the documents of the Union, you really should wonder why they waited 50 years to do that; why finally culture and education are 
on the program. It was the first time, that intellectuals and academics were called upon to construct Europe. You can say and that is the Euro-sceptic argument - historically the European Union was born with the reconstruction of Europe after fascism, so of course it was about the steel and the coal industry. We were starving remember - The Marshall Plan, we had to borrow food from the States. That's us 50 years ago, not because we are rich and powerful. We forget where we come from. So yes, it is true, it was historically necessary, but at the same time, the reason why culture could not be put on the agenda earlier, is that it would have been explosive, on the ruins of fascist Europe to open the question: What is German identity? How are the German and French going to work together? Look at now, and then imagine 50 years ago. Culture could not have been put on the agenda, because Europeans are not good at living with our differences. It would have been explosive. Even now we are not doing so great, with the long patient complicated task of comparing our differences. It could well be, that the coming of the global economy, allowed the Europeans finally to confront the internal differences without provoking a couple of world wars in the middle; without landing off a few planetary disasters in between. Maybe we can do it in our own backyard, and see, and in this sense the lowering of xenophobia and racism at the regional level is an improvement. If I celebrate the coming of cultural differences on the agenda, it is because I really rejoice the fact, that Europe is losing its centrality, as the hegemonic observatory of the planet. I really welcome the decenter of Europe, not only because in some way it is a fait a compli, but because I see it as a chance of becoming intelligent at last, of becoming critical at last, of looking at ourselves in a new self-reflexive way. We all now from the work of anthropology, from the work of feminists theories, that the view from below is an epistemologically more clear view. That the oppressed know better, that the periphery has a clearer view than the center, that the center is blinded by its own megaglomania. This has blinded our view of reality far too long. This partial situatedness can become part of how we look at ourselves, and that would be an incredible improvement on how we go about things. European feminists share this; there is something easier and there is something more attractive for Europeans to look at far-away places, rather than to stare at our own backyard. Chandra Mohanty has warned us about this: Stop constructing the other woman as the more oppressed one, that is really the liberation enlightenment from the better-knowing European free ones. Stop the construction of the Third World woman, of the East European woman, stop this processing of 'othering'.

If we take the responsibility for where we are at, if we do that, then it will be a historical chance for once, to become something other that fascist. I would argue that the idea of cultural homogeneity is the fundamental cultural myth in Europe. For example, the United States is the land of immigration; the idea that we are all part of the great melting plot - excuse me, meltingpot, and Europe is constructed as the cultural homogeneity, that is a myth. This myth is crucial to the tale of European nationalism, and through that, colonialism and fascism. In this era, this myth is being exploded. We didn't have to do anything about it. The collapse of national boundaries, the coming of waves of migrants are daily realities; whether is it migrants, exiles, refugees, post-colonial subjects, the boundaries are completely shifting. And hence the question, that I stated at the beginning, of entitlement and access, who has the rights to call oneself European. Paul Gilroys work has been pioneering on this: Can you be black and European? Can you be Muslim and European? Can you be these kind of hybrid combinations, that take on frontally the enlightenment myth of cultural 
homogenity - All white, all secular, all Christian, that does not stand to any sociological analysis. But so is whiteness, one of the radical implications of the European Union is giving us, specific location historically, that is to say a specific genealogy, a specific layered imagitiveness to non-hegemonic anti-racist whites. Historically, in our culture only white supremacist, nazis and fascist have had a discourse about being white. Being white is the absolute provocative as a discourse of essentialist white supremacists. Which makes 'whiteness' a very difficult category to analyze, and people have done good work on whiteness; whether it is Vron Ware, Ruth Frankenberg. You cannot point it out, for one - nobody wants it, and secondly, nobody is really 'white' enough. Are the Italians white? Millions of Sicilians left for the United States at the beginning of the century - we are not white - it breaks down into categories. Whiteness is a form of invisibility, which Frankenberg points out, gives you structural privileges. It is a universalistic positions. It becomes confused with being human. Black is a problem - white is not. Analogous to what masculinity was, before the feminist wave came in like a thunder, and took care of that one. The first thing you have to do, is to name it for what it is, and look at the structure relation of power that whiteness contains. The process of naturalization and invisibility of whiteness makes it clinialogically slippery, it is very difficult to do anti-racist work with whiteness, because it is not a category. Irishness, Jewishness, Italianess is not a problem. In this framework, Ruth Frankenberg calls for a radical embodiment of whiteness. Take on the responsibility for what it means. And if you do not know what it means, go and read what Bell Hooks has written about it, go read what Tony Morrison has written about it, because women of color has a better perception of you little invisible zombie. We have yet a possibility of a radical strategy of countability, that would get the whites off the escaperoute which are either denial or guilt. Give it a chance to take on seriously, consciencely, in a sober manner a multilayered complex-loaded identity and to rework it in a way it would open, and make it into a contestant identity. Do not let somebody then tell you what whiteness should be, do not let this chance go. When we look at race and multiculturalism that are being taught in women's studies in Europe, then what we noticed, was that everybody was adopting the American agenda, so we are all up to-date on this trans-atlantic problem on racism, but nobody is looking into their own back-yard. It is what I call the alibi of borrowing the post-colonial black-American agenda, instead of avoiding the issues that hurt. Whether it is the people, that we push off shore at Gibraltar, we don't want to know because it hurts. One of the inevitabilities of our historical conditions, is that whites have to put up with some pain, maybe it has to hurt for a little while. Maybe it is the way for us, to waken up and to make our systems or societies wake up of the long slumber, of this fantasy of centrality, which has caused us so much pain, and which has caused the world so much sorrow. The European Union is for me such a chance, I know that for everything I say, you can think of five or six counterarguments, but my argument remains, unless we do something about it, this is going to go wrong. Unless we get involved in this contestant identity, in a spirit of freedom of justice, this is going to go very wrong, and Fortress Europe will be cemented on our backs, and will be a disastrous construction, if we do not do something about it. Nietzche argued earlier on in the century, that many Europeans no longer feel at home in Europe. At the closing of this century, I argue, those who no longer identify with Eurocentrism in this dominant mode, now have this historical chance of reframing $\mathrm{Eu}^{-}$ rope, and making it accountable, for a history, in which fascism, imperialism, domination played a central role, though I main- 
tain it is only part of the history and there is much more to Europe than that. We need to get accountable also for the history, I'm really not too optimistic, but I really wanted this to be the last word.

Rosi Braidotti

Coimbra, Portugal, Juli 1997

\section{SUMMARY}

The article contributes to the international feminist theory debates on contemporary subjectivity, sexual difference, and diversity. The focus of the article is on the interrelation be- tween the multilayered understanding of subjectivity, based on sexual and ethnic differences, and the diversity in contemporary social thought. The emphasis is placed on the quest for new models of 'flexible citizenship' within the European Union.

Rosi Braidotti.

Chair of Women's Studies. Scientific Director of the Netherlands Research School of Women's Studies. Academic Coordinator of the European Inter-University network NOISE and the thematic network ATHENA, both within the Socrates program of the EU. 